\title{
STUDENTS' LEARNING MOTIVATION THROUGH EDMODO: BLENDED LEARNING IN ESP CLASSROOM
}

\author{
Merie Agustiani $^{1(*)}$, Sulia Ningsih ${ }^{2}$, Anggraeni Agustin Muris ${ }^{3}$ \\ Universitas Baturaja, Sumatera Selatan, Indonesia ${ }^{123}$ \\ merie_piecery@fkip.unbara.ac.id ${ }^{1}$, sulia_ningsih@ fkip.unbara.ac.id ${ }^{2}$, \\ anggraeni_agustinmuris@ fkip.unbara.ac.id ${ }^{3}$
}

$\begin{array}{ll}\text { Revised: } 11 \text { Desember } 2020 \\ \text { Accepted: } & 07 \text { Januari } 2021\end{array}$

\begin{tabular}{ll}
\hline Received: & 09 Oktober 2020 \\
Revised: & 11 Desember 2020 \\
Accepted: & 07 Januari 2021
\end{tabular}

\begin{abstract}
The advent of technology requires educators to bring technology into the classroom to involve the students as digital-native. Without having a motivation, a student or even a teacher or reader is unable to reach the learning objectives. Virtual worlds are believed to become creative complementary tools to inspire and enable the students to learn independently. They are widely used and blended with face-to-face learning in the teaching and learning process. This study focused on how Edmodo could raise students' motivation. This descriptive study involved forty-four students of Education Technology Study Program of Baturaja University who took the English course in the second semester of academic year 2019/2020. The data were collected through a questionnaire with twenty questions and analyzed by using descriptive statistics. The result showed that students were instrumentally motivated in learning English and students' performance goal was higher than their learning goal even though there was no significant difference between the performance and learning goals.
\end{abstract}

Keywords: Blended Learning; Edmodo; Students' Motivation

(*) Corresponding Author: $\quad$ Agustiani, merie_piecery@fkip.unbara.ac.id, +62 81272149991

How to Cite: Agustiani, M., Ningsih, S., \& Muris, A. A. (2021). Students' Learning Motivation Through Edmodo: Blended Learning In Esp Classroom. Research and Development Journal of Education, 7 (1), 3949.

\section{INTRODUCTION}

Without having a motivation, a student or even a teacher or reader is unable to reach the learning objectives. This is an observation commonly found to be linked to the positive cycle of teaching and learning. Komara and Ramdani (2014) point out "motivation has a very crucial role in a learning process, especially related to the students' achievement in mastering a particular subject". In its relation to EFL teaching, Al-Othman and Shuqair (2013) point out that Motivation has been widely recognized by scholars, researchers and teachers as one of the key variables for determining secondlanguage learning (SLA) levels and successes. Motivated learners are motivated, eager to work hard, concentrate on the assigned tasks, do not require constant reinforcement, face challenges enthusiastically, and may even inspire others, promoting collaborative learning.

Bauer and Erdogan (2012) explain that performance is a feature of the relationship between the motivation, ability, and environment of a person. We can see from the argument that motivation is one of the crucial keys to the success of individuals. Motivation is one of the factors contributing to achievement. Motivation is defined as the ultimate purpose or a certain level of success, contributing to action that is goal-directed. We mean that the person is trying hard to complete the assigned tasks when we refer to 
someone as becoming motivated. Motivation is obviously necessary if anyone is to perform well; it is not enough, however. Ability is also critical and is often the main determinant of effectiveness, or having the skills and expertise necessary to carry out the job. Finally, environmental factors are crucial to deciding success, such as having the tools, information and support one requires to perform well. At various times, the secret to high performance could be one of these three variables.

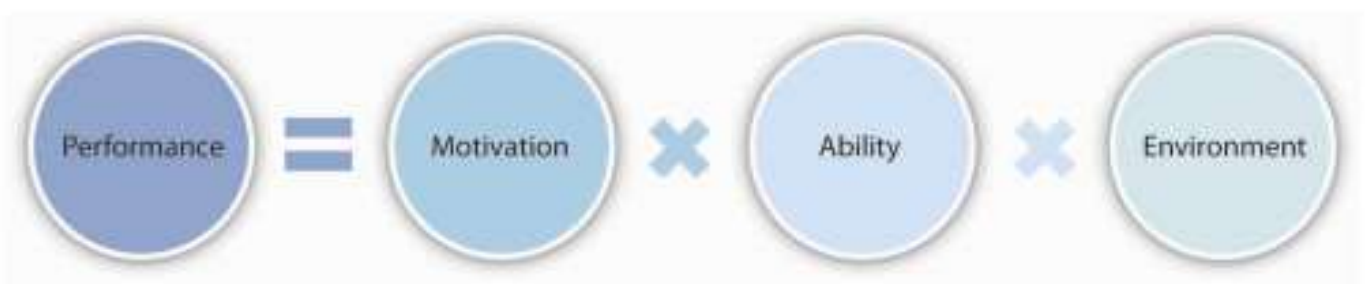

Source: Bauer and Erdogan (2012)

Figure 1.

Influencing factors of individual's performance

Further, Zhang, Dai, and Wang (2020) point out that among the most frequently discussed topics in SLA literature are motivational orientations, and various theoretical frameworks have been developed to profile the motivation of L2 learners. Garner's early formulation approach on motivation has been widely recognized and used in language learning literature. The framework introduces two kinds of motivational orientation; (1) instrumental motivation and (2) integrative motivation. Instrumental and integrative motivations reflect the willingness of a learner to satisfy their internal and external needs, which are closely linked to their mental situation. In order to gain career advantage, instrumental motivation would encourage English majors to enhance their second foreign language skills, while integrative motivation would push them, out of interest, to frequently direct themselves to the target language. Learners will be more dedicated to their second foreign language learning with such positive motivations and objectives, aiming to gain greater enjoyment from the process and thus develop more positive emotions. Therefore we can conclude that such positive motivations will improve the level of enjoyment in second foreign language learning, whether instrumental or integrative.

Affandi and Hastjarjo (2011) describe two kinds of the motivational goal of students' learning; performance goal and learning goal. Performance goals are part of the achievement goal theories, where performance goals are defined as goals demonstrating ability or avoiding showing abilities that it feels unable to perform. Focus on performance the goal lies in completing the task. Meanwhile learning goals are goal setting framed to focus on developing knowledge and skills of a task and mastery of tasks. The focus of learning goals lies in the process and not on the end result. Greg (2018) describes the aims of learning and performance can also cause numerous implicit intelligence conceptualizations. Learning objectives aim to induce an incremental theory of knowledge conceptualization that is mastery-oriented and resilient to negative feedback. Performance goals tend to cause an intellect conceptualization paradigm of an individual that is not responsive to negative feedback. As a consequence, people assigned a performance goal can more easily abandon their learning attempts.

The Information and Communication Technology (ICT) of the $21^{\text {st }}$ century has brought numerous benefits to various aspects of living. ICT, in fact, is abundant from experienced science defines modern life (Hussain, 2018). Therefore, in the rapid advancement of technology nowadays, educators should be able to focus on highlighting a deep understanding as part of the education support system and engage students with 
real-world data and tools. Teachers should be able to integrate the use of supporting technology, problem-based approaches and higher-order thinking skills in learning strategies (Cakrawati, 2017).

Many empirical studies have considered the importance of teaching and learning through technologies of all subjects, in which English is no exception. Students rely heavily on their teachers to make them passive learners throughout the conventional English classroom settings, while mixed learning allows students to be independent and more accountable for their own learning (Hariri \& Bahansal, 2015). A blended learning instructional model is currently popular among teachers of EFL/ESL who thought it would be beneficial to create a new and dynamic atmosphere during the learning of target language. Through a blended-learning use, students receive guidance, speech delivery practice, receive feedback from peers and teachers on their speech success that can hopefully improve their oral skills and motivation in the EFL classroom. This model gives teachers the possibility to combine face-to-face teaching with computer-mediated or online learning. Rodrigues and Vethamani (2015) mentioned that the effect of Information and Communication Technology (ICT) on education has been demonstrated in numerous studies because it makes teaching and learning more interesting, engaging, meaningful and also motivates students.

Rodrigues and Vethamani (2015) describe that the concept of technology-based language learning has allowed both language teachers and learners to explore the effectiveness of an online learning approach. Such computer-mediated activities provide an online platform for ESL learners to continue to practice their language skills since their learning hours of face-to-face contact are limited. Limited contact learning hours impact ESL learners who wish to further improve their oral skills in classroom. Additionally, Wichadee (2017) believed that, in a blended course, conventional learning is supplemented with the use of proper learning technologies. Using technologies with new teaching methodologies can create innovative learning environments that allow instructors to more efficiently organize their teaching. For example, time in the classroom may be spent teaching material appropriate for face-to-face meetings.

For their daily activities, most students rely on the internet including their academic needs. For this reason, setting up an online system or student portal is appropriate to satisfy their academic needs. This online portal helps the students to search for and get information about their courses. Learning Management System (LMS) is one such system that can be used by education institution all over the world. Adzharuddin and Ling (2013) describe that LMS is a web-based technology that is used to monitor, control and administer the learning system and is especially used in the learning environment.

Edmodo is one of the online learning supplementary tools which is widely used in the EFL classroom. It is commonly referred to as "facebook" in education, since it is an educational website of social networking. Edmodo, one of the learning management systems, was created in 2008 by Nic Borg and Jeff O'Hara, who realized the need to evolve the school environment in order to meet the connections of the world of the 21st century (Gushiken, 2013). It is a social learning network designated by teachers, parents and students alike as ' Facebook for Schools ' or ' Facebook look alike. '. Edmodo is a free and secure educational learning network that provides teachers with a simple way to create and manage an online classroom community, also allows students to connect and work with teachers of their classmates anywhere and anytime. (Balasubramanian, Jaykumar, \& Fukey, 2014). Rahma (2012) also points out that Edmodo is an educational technology that offers online classroom communication and collaboration, and provides learners and educators with a more secure learning platform. Manowong (2016) points out that Edmodo is a potential innovative tool which offers a lot of educational benefits. 
There are lots of useful features on the Edmodo. With just a click away, the platform can be used to facilitate online learning opportunities as well as enhanced classroom interactions and resource sharing. This research was therefore conducted to see how Edmodo could promote encouragement for the students.

In English language teaching at Baturaja University, traditional teaching methods are still commonly used in all majors. Discussion, presentation, role-playing, games, and others are held in face-to-face instructions. Gay and Sofyan (2017) argued that a student entering college without distance learning experience may be at a disadvantage in the near future since many interactive learning environments and other educational resources are accessible free of charge on the internet and can be accessed by teachers and students Hence, some countries allow students to take online course as prerequisite for high school graduation. Many colleges often include online courses in their curriculum. Therefore, a new innovation in English teaching is needed at Baturaja University to enable both lecturers and students to keep up with the times, particularly in the era of the 4.0 industrial revolution. Students are encouraged to work within the project structure and to communicate with their peers, lecturers and the outside world. Alternatively, the emergence of new ways of interaction is important. This study of blended learning was then conducted in exchange to familiarize the students with some additional features using computer-mediated learning to support their successful learning

\section{METHODS}

This study was conducted at Baturaja University through cross sectional survey design that the data were collected at one point in time after the speaking class. The choice of a cross sectional survey design was carried out to measure the behaviour of a number of populations through a sample regarding the level of academic integrity of students as a variable in the study. It is a consideration that the cross sectional survey design is a popular survey design used in education, and is used to gather information about attitudes, beliefs, opinions, and behaviours with the advantage of being able to present information in a short time. In this study, a cross sectional survey was used to find out the information about students' learning motivation in learning English through EDMODO.

Forty four students majoring in Education Technology who took English Course in the second semester of academic year 2019/2020 participated in this study. They were chosen through simple random sampling from the total number of population of the study. In collecting the data, a questionnaire, adapted from Vaezi (2008), Komara and Ramdani (2014) and Cakrawati (2017) were used. It consisted of 20 questions using Linkert scale survey questionnaire that was aimed at finding out the students' reasons for learning English, performance and learning goals of the students using Edmodo. The quantitative data were analyzed through descriptive statistics to determine the mean (M) and the standards deviation (SD) for each item of the questionnaire, then it was interpreted descriptively.

\section{RESULTS \& DISCUSSION}

\section{Results}


The results of this study were obtained from 44 students who filled 20 items of the questionnaire. There were three important parts from its result; (1) the student' reasons; (2) performance goal, and (3) learning goal of learning English through Edmodo.

The result of student' reasons of learning English was mostly because they need English to support their future career $(\mathrm{M}=4.53 \mathrm{SD}=0.49)$, being skilled in English can lead to more lifelong success and achievements. ( $\mathrm{M}=4.47 \mathrm{SD}=0.53)$, and getting English skills makes others respect them $(\mathrm{M}=4.40 \mathrm{SD}=0.55)$. Table 1 showed the detailed information about the reason why students learn English:

Table 1.

Student's Reasons for Learning English

\begin{tabular}{clccc}
\hline No & \multicolumn{1}{c}{ Statement } & M & SD \\
\hline 1. I need English for my future career & 4.53 & 0.49 \\
2. & $\begin{array}{l}\text { Being skilled in English can lead to more lifelong success and } \\
\text { achievements. }\end{array}$ & 4.47 & 0.53 \\
3. & Getting English skills makes others respect me & 4.40 & 0.55 \\
4. & $\begin{array}{l}\text { Learning English is important to make a person skillful and } \\
\text { knowledgeable. }\end{array}$ & 3.83 & 0.65 \\
5. & $\begin{array}{l}\text { Studying English helps me understand English books, movies, pop } \\
\text { music, and so on. }\end{array}$ & 3.67 & 0.65 \\
6. Studying English allows me to maintain contact with foreign & 2.87 & 0.62 \\
& $\begin{array}{l}\text { acquaintances. } \\
\text { 5tudying English helps me become an open-minded and sociable } \\
\text { person, like people who speak English. }\end{array}$ & 2.83 & 0.64 \\
\hline
\end{tabular}

Source: Researcher (2020)

For the student's performance goal in learning English by using Edmodo, it was obtained that the students were afraid of losing score due to their late submission of the assignment $(\mathrm{M}=4.57 \mathrm{SD}=0.50)$ and tend to be considered as active students $(\mathrm{M}=4.17$ $\mathrm{SD}=0.58)$.

Table 2.

Students' Performance Goal

\begin{tabular}{llll}
\hline No & Statement & M & SD \\
\hline 8. & I don't want to post the assignment in EDMODO late to avoid losing score & 4.57 & 0.50 \\
9. & I need to be active in EDMODO so I'll be notified by the lecturer. & 4.17 & 0.58 \\
10. & After I have finished doing all the EDMODO quizzes, I am sure I can do & 3.53 & 0.67 \\
& the test & $\mathbf{4 . 0 9}$ & $\mathbf{0 . 4 3}$ \\
\hline
\end{tabular}

Source: Researcher (2020)

For students' learning goal, the students admitted that Edmodo is an interesting learning tool. It can be seen from the mean scores $4.37(\mathrm{SD}=0.66)$. Furthermore, lecturer's feedback in Edmodo makes the students be better $(\mathrm{M}=4.47 \mathrm{SD}=0.73)$, the students also agreed that the reference materials (videos, powerpoint files, articles) and assignments posted by the lecturer in Edmodo help them to improve their learning and understand the contents/ topics of the lesson better $(\mathrm{M}=4.20 \mathrm{SD}=0.75)$. In addition, the students agreed that they could get more explanation by posting more questions through Edmodo(M=4.07 $\mathrm{SD}=0.85)$ and practice their language skills $(\mathrm{M}=4.27 \mathrm{SD}=0.57)$. Table 3 presents the result of the students' learning goals.

Table 3.

Students' Learning Goal 


\begin{tabular}{|c|c|c|c|}
\hline No & Statement & $\mathbf{M}$ & SD \\
\hline 11. & I like to learn English through EDMODO because it's interesting & 4.37 & 0.66 \\
\hline 12. & It is easy to operate EDMODO & 3.80 & 0.79 \\
\hline 13. & Being active in EDMODO makes me comprehend more the lesson & 3.17 & 0.73 \\
\hline 14. & Feedback from lecturer at EDMODO inspires me to be better than before & 4.47 & 0.56 \\
\hline 15. & $\begin{array}{l}\text { EDMODO's presence meets my learning needs both in consulting and in } \\
\text { discussions with the lecturer }\end{array}$ & 3.87 & 1.12 \\
\hline 16. & $\begin{array}{l}\text { All the activities I've done at EDMODO make me more aware that a } \\
\text { process is needed to achieve the learning goal. }\end{array}$ & 3.53 & 0.88 \\
\hline 17. & $\begin{array}{l}\text { The reference materials (videos, powerpoint files, articles) and } \\
\text { assignments my teacher has posted in EDMODO help me improve my } \\
\text { learning and better understand the content / themes of the lesson. }\end{array}$ & 4.20 & 0.75 \\
\hline 18. & $\begin{array}{l}\text { Online activities and discussions in EDMODO can motivate me to learn } \\
\text { more about the lesson. }\end{array}$ & 3.67 & 0.98 \\
\hline 19. & Activities in EDMODO help me practicing my language skills & 4.07 & 0.85 \\
\hline \multirow[t]{2}{*}{20.} & $\begin{array}{l}\text { I post questions in EDMODO in order to get more explanation both from } \\
\text { the lecturer and other students. }\end{array}$ & 4.27 & 0.57 \\
\hline & & 3.94 & 0.39 \\
\hline
\end{tabular}

Source: Researcher (2020)

However, there were few of students who had complaints on the use of Edmodo in learning classroom. Those complaints were told to the researchers and the instructor in the middle of the face-to-face instruction was held after having two meetings with Edmodo. The students' statements were as follows:

Table 4.

Students' Complaints on the Use of Edmodo

\begin{tabular}{ll}
\hline Students' Initials & \multicolumn{1}{c}{ Statements } \\
\hline MS & I need to ask some extra money to my parents for buying internet \\
quota. & $\begin{array}{l}\text { It is more comfortable for me to practice speaking English directly } \\
\text { in the classroom, so you can check whether I pronounce the word } \\
\text { correctly or not. }\end{array}$ \\
When we have online class with Edmodo, I am in my hometown \\
WM & $\begin{array}{l}\text { where it is hard for me to get good internet connection. So I lost my } \\
\text { score for one assignment. }\end{array}$ \\
AS, LA, RA, LJ, FO & $\begin{array}{l}\text { I have poor connection, so I need more additional time to finish and } \\
\text { submit my works. }\end{array}$ \\
GH, FT, TK & Edmodo is a new thing for me. Hence, I need more time to adapt in \\
& using it.
\end{tabular}

Source: Researcher (2020)

\section{Discussion}

Dealing with the findings above, the three highest mean scores of student' reasons in learning English are because they need English to support their career, lead to be more successful and reach their achievements in life, and also to be respected by others. The students had a higher degree of instrumental motivation than the integrative one, even though it was not too significant. 


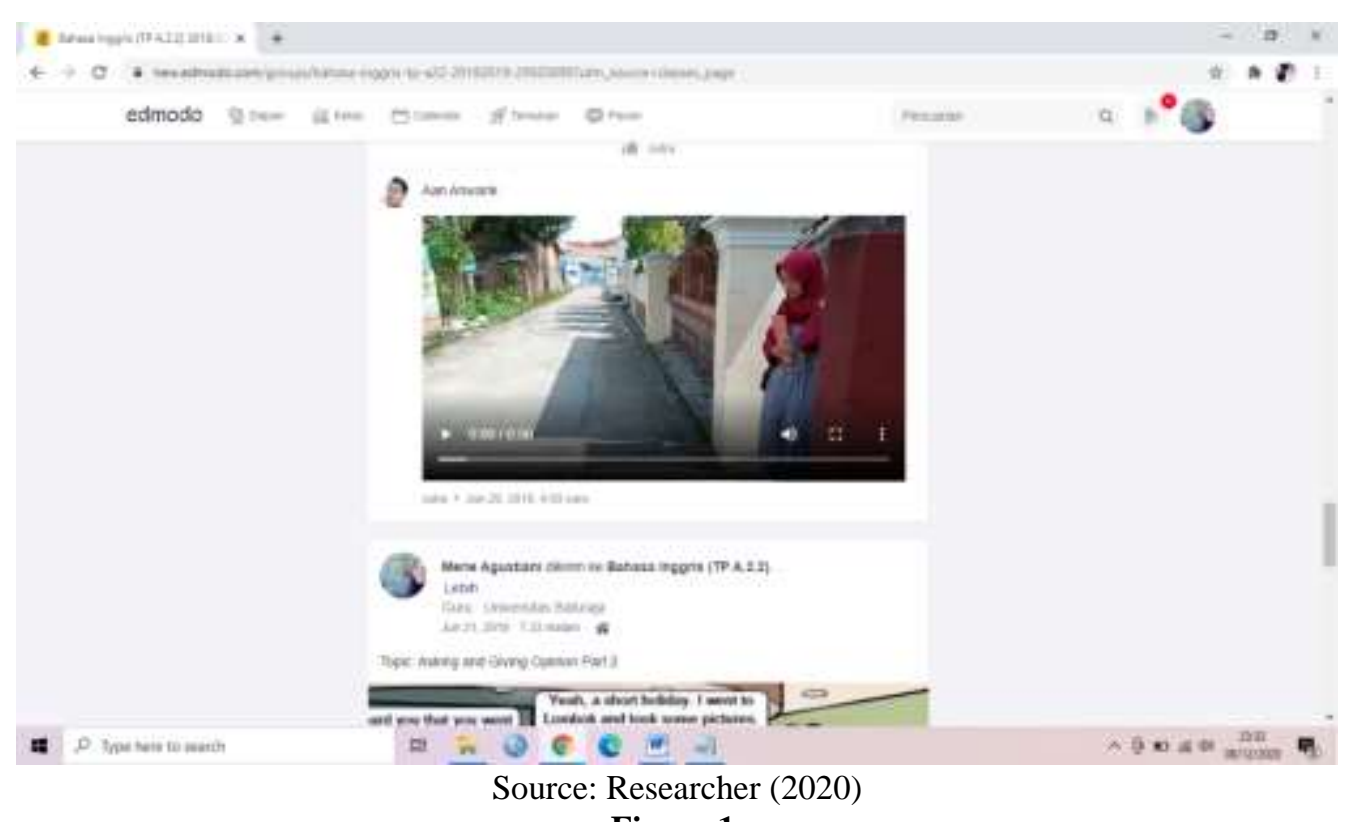

Figure 1.

The Students' Speaking Learning Ativities on EDMODO

This finding was quite similar to the findings of Vaiezi (2008) who investigated the language learning motivation among Iranian undergraduate students. The result of his study revealed that Iranian undergraduate students were significantly motivated by instrumental motivation. Since the sample of this study was the students who were not major in English, but majoring in Educational Technology, they considered English as a general course that must be taken by all the students of all majors in the second-semester academic year 2018/2019, meaning that English teaching was held because of specific purposes. Javid (2015) points out that ESP courses (both academic and professional) are designed for students who want English in a post-academic setting or for those who want it in a pre-occupational setting for academic purposes. Therefore, instrumental motivation was higher than integrative motivation.

In addition, regarding the use of Edmodo in blended learning in ESP context, the students' performance goal was higher than their learning goal. Most of the students were afraid of losing scores when they were late submitting the assignments and they wanted to be noticed as active students by the lecturers. A study revealed by Uzun (2015) pointed out that all students wanted online access for the content of the course, though they did not prefer to take online courses. They wanted to be involved in the classroom and through Edmodo as learning management tool, they wanted to build a warm relationship with the instructors.

The students believed that they would get good scores if they were active in various activities given by the lecturer through Edmodo. Both acknowledged, however, that learning through Edmodo gave them a new experience, and found it important to use Edmodo. This is because of the inherent interest of many students in all things concerning technological learning. Besides, Edmodo provides the students readings, learning resources, various activities and tasks posted by the teachers/ lecturers which can be accessed both during and outside the scheduled class period. Students can log in to their accounts wherever they have internet connection (Gay and Sofyan, 2017). After all, the materials and audio or video posted by lecturer to help them in understanding the material. Manowong (2016) found that Edmodo could promote active participation in 
online class activities, and students could access the site to allow easy and convenient use of the reference materials.

Ignoring whether the students are more inclined towards instrumental or integrative motivation and whether their performance goals are higher that learning goals when learning using Edmodo as supplementary tools in blended learning, the students in common admitted that Edmodo is a good and interesting media to use that can grow their motivation to learn. This result was very good since the greater students' participation and motivation would be the higher their learning outcomes. Triarisanti and Purnawarman (2019) stress the high level of interest and motivation has influenced students' learning outcomes. Every learner is still interested in learning, no matter how small the interest is. Teacher or lecturer should be able to grow learner curiosity and accommodate the learners in order to make them try better with the lessons. Additionally, the study of Surjono, Muhtadi and Wahyuningsih (2017) indicated that students received the blended instruction had higher success levels and higher participation rates than students who attended the conventional instruction.

Javier and Dirain (2018) explain that using technology with new teaching methodology will build a state of the art learning atmosphere that allow teachers to more efficiently and effectively develop their teaching, which it can give more positive impact to students' learning achievement. The respondents of their study strongly agreed with Edmodo on ease, encouragement, and usefulness. Additionally, using Edmodo application can enhance students' learning self-efficacy. It makes students more confident and increases self-confidence among students (Maulana \& Sapta, 2017).

Some people believe the use of technology in blended learning eliminates the process of students' social contacts. In fact, this is a wrong assumption because blended learning can actively encourage students to communicate outside the classroom not only physically but also via online communication. Discussions occur either offline or online in the classroom (Zainuddin \& Keumala, 2018).

Regarding to the result of students' complaints on using Edmodo, Etfita (2019) argued that besides giving positive perspectives on the use of Edmodo, some students, in fact, feel that Edmodo is not good supplementary tool. Although most of the students perceived Edmodo as user-friendly, realistic, time-saving, enjoyable, and inspiring as the platform's advantages, The students, however, have shown negative reactions to Edmodo by saying it is sluggish, frustrating, and needs constant internet connection.

Leliani, Agustiani, and Maryani (2014) tell that ICT will improve the enthusiasm of learners. Through ICT integration in teaching and learning processes, learners can become engaged with technology in a new environment. Unfortunately, restricted availability of facilities and internet connectivity will be possible challenge to the internet integration into classroom settings. Indeed, in contrast to its many benefits, learning through the hybrid concept often has limitations that need to be addressed. One of the challenges is to demand that teacher has to be carefully prepared to implement this method. Teachers should have the skills to use the technology and spend a lot of time developing the system, particularly during the initial period of implementation. They should take plenty of time to prepare the material according to this method, set up evaluation method and be involved 24 hours a day in the learning experience to respond and give statement on the Learning Management System (LMS) online forum (Zainuddin \& Keumala, 2018).

Traditions, financial, political, and beliefs all play significant role in every society. The physical and geographical positions of a community will further encourage the degree to which these socio-cultural factors are relevant to educational matters (Al Hunaiyyan, Al Huwail, \& Al Sharhan, 2008). The online learning process forces learner to study independently and show high enthusiasm while they cannot have face-to- 
face interactions with teacher and friends. From the perspective of culture, the essence of the online learning is more consistent with the ideology of low power distance and high individualism. Because Indonesian tends to exhibit high power distance and low individualism, online learning is quite incompatible with the culture of Indonesia. Therefore, some instructional designs are required to resolve the question of compatibility (Hanoum \& Silvana, 2019).

However, the most challenging issue to ICT integration in the classroom is the conventional way of teaching or old fashioned way of transmitting knowledge to the students. It is believed that in conventional way of teaching, students can understand more from the explanation of teachers and the involved listeners. This style of method has reached a deep root in educational activities that is impossible to shift the mind of those educated in this method. As a result, changing the attitude of the instructors and installing ICT programs into classroom instruction is becoming a problem nowadays. Sometimes, breaking old habits and adapting to new technical development, is challenging (Tedla, 2012).

\section{CONCLUSION}

The findings of this study present an image that studying English was instrumentally inspired by students with a major in Education Technology. This study confirms the perspectives of some researchers who claim the students are mostly instrumentally focused in an EFL situation. The instructor, the class environment, the course content, resources, and facilities as well as the student's personal characteristics dictated the individual's learning motivation in the classroom. The students' positive experience in using Edmodo in English language learning, particularly in non-English major, motivates the students to be the independent learners with the help of a wide range of authentic materials posted by the lecturer. Using Edmodo in ESP context can encourage students to engage actively in various learning activities. Edmodo is a proven potential additional tool to support face-to-face instruction as it facilitates communication and collaboration between students and lecturers.

The findings in this study encourage universities to foster learning environment that use integrated approaches to learn in their courses. Student-center learning environment can be created since students are known to be more involved and more interested in learning experience through blended learning.

\section{ACKNOWLEDGEMENT}

Highest appreciation for the Research, Technology and Higher Education Ministry who has funded this research. A great appreciation was also given to all students and coresearchers who involved in completing this research.

\section{REFERENCES}

Adzharudding, N.A. \& Ling, L.H. (2013). Learning Management System (LMS) among university students: Does it work?. International Journal of e-Education, $e$ Business, e-Management and e-Learning, 3(3), 248-252 
Affandi, G.R. \& Hastjarjo, (2011). Pengaruh Tipe Penentuan Tujuan (Goal Setting) terhadap Performansi Bahasa Inggris Siswa: dengan Efikasi Diri dan Kemampuan Awal Bahasa Inggris sebagai Kovariabel. Jurnal psikologi, 6(1), 277-288.

Al Hunaiyyan, A., Al Huwail, N. \& Al Sharhan, S. (2008). Blended E-Learning Design: Discussion of cultural issues. International Journal of Cyber Society and Education, 1(1), 17-32.

Al-Othman, F.H. \& Shuqair, K.M. (2013). The impact of motivation on English language learning in Gulf States. International Journal of Higher Education, 2(4), 123-130.

Balasubramanian, K., Jaykumar, V., \& Fukey, L. (2014). A study on Student preference towards the use of Edmodo as a learning platform to create responsible learning environment. Social and Behavioral Sciences, 144, 416-422. doi: 10.1016/j.sbspro.2014.07.311

Bauer, T. \& Erdogan, B. (2012). An introduction to organizational behavior. Retrieved from https://2012books.lardbucket.org/pdfs/an-introduction-to-organizationalbehavior-v1.1.pdf

Cakrawati, L.M. (2017). Students' perceptions on the use of online learning platforms in EFL classroom. English Language Teaching and Technology Journal (ELT-Tech Journal), 1(1), 22-30.

Creswell, J.W. (2012). Educational research; planning, conducting, and evaluating quantitative and qualitative research ( $4^{\text {th }}$ ed.). Boston, MA: Pearson Education, Inc.

Etfita, F. (2019). Students' perspective on the use of Edmodo as an assessment tool. Jounal if English for Academic, 6(1), 18-25.

Gay, E. \& Sofyan, N. (2017). The effectiveness of using Edmodo in enhancing students' outcomes in advanced writing courses of the fifth semester at FIP-UMMU. Journal of English Education, 2(1), 1-11.

Greg, R. (2018). Working Smarter and Working Harder: Combining Learning and Performance Goals to Improve. Retrieved from https://uwspace.uwaterloo.ca/bitstream/handle/10012/14269/Richins_Greg.pdf?seq uence $=3$ \&isAllowed $=y$

Performance in a High-Complexity Task Environment. Retrieved by https://uwspace.uwaterloo.ca/bitstream/handle/10012/14269/Richins_Greg.pdf?seq uence=3\&isAllowed=y Gushiken, B. (2013). Integrating Edmodo into a high school service club: To promote Interactive online communication, 18th Annual TCC online conference, Hawai, USA

Hanoum, N. \& Silvana, H. (2019). Instructional needs analysis and cultural values in online learning. International Journal of Education, 12(1), 9-15. Doi: 10.17509/ije.v12i1.17776

Hariri, R.O. \& Bahansal, D.A. (2015). Maximizing L2 interaction through using Edmodo in Saudi EFL classroom. International Journal of Linguistics, Literature, and Culture, 2(4), 48-60.

Hovhannisyan, I. (2014). Learners attitude and motivation to learn English: English as foreign or as an international language? Retrieved from http://ikee.lib.auth.gr/record/135286/files/Iren\%20Hovhannisyan\%20Doctoral\%20 Thesis\%20Final.pdf

Hussain, Z. (2018). The effect of ICT-based learning on students' vocabulary mastery in junior high school in Bandung. International Journal of Education, 10(2), 149-156. doi: http://dx.doi.org/10.17509/ije.v10i2.7592

Javid, C.Z. (2015). English for specific purposes: Role of learners, teachers, and teaching methodologies. European Scientific Journal, 11(20), 17-34. 
Javier, B.S. \& Dirain, E.L. (2018). Edmodo as supplemental tools to blended learning: The case of Fillipino university students. International Journal of Science and Research, 8(6), 352-357.

Komara, U. \&Ramdani, J. M. (2014). Motivating students through Edmodo (a blended learning in grammar class). A paper presented in the $61^{\text {st }}$ TEFLIN International Conference, UNS Solo.

Leliani, S., Agustiani, M. \& Maryani, L. (2014). Integrating ICT to EFL classroom. Proceedings of Sriwijaya University Learning and Education International Conference, Palembang, May 16-18. Retrieved from http://repository.unsri.ac.id/13721/1/25. Septi Leliani\%2C Merie \%26 Lina.pdf

Manowong, S. (2016). Undergraduate students' perceptions of Edmodo as supplementary learning tool in an EFL classroom. Silpakorn University Journal of Social Sciences, Humanities, and Arts, 16(2), 137-161.

Maulana, C. \& Sapta, A. (2017). Use of Edmodo in improving self-efficacy. Proceeding International Psychology, Education Counceling, and Social Work Conference, $25^{\text {th }}-27^{\text {th }}$ August, 5-8.

Rahma, N.A. (2016). Edmodo as E-learning media in teaching speaking descriptive text for tehth grade of SMAN 12 Surabaya. RETAIN, 4(2). Retrieved from http://jurnalmahasiswa.unesa.ac.id/index.php/retain/article/view/15925

Rodrigues, P.D. \&Vethamani, M.E. (2015). The impact of blended learning in the development of speaking skill. Journal of Interdisciplinary Research in Education (JIRE), 5(1), 43-67

Sujono, H.D., Muhtadi, A. \& Wahyuningsis. (2017). The implementation of blended learning in multimedia courses for undergraduate students in Indonesia. International Journal of Information and Education Technology, 7(10), 784-786.

Tedla, B.A. (2012). Understanding the importance, impact, and barriers of ICT on teaching and learning in East Africa countries. International Journals for $e$ Learning Security, 2(2), 199-207.

Triarisanti, R. \& Purnawarman, P. (2019). The influence of interest and motivation on college students' language and art appreciation learning outcomes. International Journal of Education, 11(2), 130-135. Doi: 10.17509/ije.v11i2.14745

Uzun, E. (2015). Students' attitude toward the use of Edmodo as a supplementary tool for highe education. Participatory Educational Research, Special Issued 2015-11, 78-83. doi: http://dx.doi.org/10.17275/per.15.spi.2.10

Vaezi, Z. (2008). Language learning motivation among Iranian undergraduate students. World Applied Sciences Journal, 5(1), 54-61.

Wichadee, S. (2017). A development of the blended learning model using edmodo for maximizing students' oral proficiency and motivation. iJET, 12(2), 137-154

Zainuddin, Z. \& Keumala, C.M. (2018). Blended learning method within Indonesian higher eduction institution. Jurnal Pendidikan Humaniora, 6(2), 69-77.

Zhang,H., Dai, Y., \& Wang, Y. (2020). Motivation and second foreign language proficiency: The mediating role of foreign language enjoyment. Sustainability, 12, 1-13. doi:10.3390/su12041302 